\title{
Telling Another Story: Women's Documentaries as Counter-Narration in Independent Algeria
}

\begin{abstract}
This essay analyses seven documentaries made by Algerian and Franco-Algerian female directors as examples of counter-narration in the contemporary Algerian and French public spheres. After a brief introduction to the historical context of creating the official discourse, whether colonialist or nationalist, the study starts with an analysis of the documentaries (made between the 1970s and the 2010s), then briefly highlights their technical characteristics, contents, and purposes. In relation to their historical and political context of production and reception, the documentaries reveal the directors' awareness of exclusion or marginalisation of their subjects as a pretext for the films' realization. Therefore, they attempt to complete the official narration created by colonialism, nationalism, and patriarchy. More precisely, the documentaries try to deconstruct the public discourse and the mechanisms that make the mythological machine of official discourses so effective, introducing new languages, techniques, and meanings into the public sphere. Furthermore, documentaries are future-oriented, since they aim to collect and preserve the memories of crucial episodes of history, however painful and traumatic they might be, in order to be treasured for future generations. In addition, they often show examples of empowerment and agency that have been lost or eliminated over time. This analysis, which can be extended to a larger number of documentaries, directors, and subjects, aims to demonstrate that colonialist and nationalist public discourses have silenced alternative perspectives; however, the official narration is increasingly being opposed through the represen-

Silvia MASCHERONI tation of forgotten episodes and protagonists of history.
\end{abstract}

Independent researcher absa.silvia@gmail.com

EKPHRASIS, 1/2021

COUNTERDISCOURSES AND

COUNTERPUBLICS IN CINEMA, ART, MEDIA AND LITERATURE pp. 125-142

DOI: $10.24193 /$ ekphrasis. 25.9

Published First Online: June 21, 2021
Keywords: women's documentary, postcolonial Algeria, representation, counter-narration, memory, history.

\section{Introduction}

Since achieving independence in 1962, Algeria has begun its postcolonial and democratic history. As the first European colony in Africa and a French colony from 1830 to 1962, Algeria has been 
described as the most vile and shameful example of systematic colonization (Stone 31). The French colonial regime made use of all possible means to impose its supremacy and control over Algerian territory and population: violent repression of dissent, deportation of rural populations to camps, systematic use of torture, war, control of means of information and artistic production - these were all instruments adopted by the colonial regime in order to reduce the colonized to the condition of mere objects of history, controlled and narrated by the colonizer (Stora, La guerra d'Algeria 86). French colonial history in Algeria ended in 1962. However, in addition to the neo-colonial forms that persisted over time, the narration of the colonial past has continued and, with it, the mystification (or even the cancellation) of some episodes. The Algerian War of Independence was recognized as such only during the '90s, whereas previously it was referred to as the "events in North Africa." In the 2000s, a bill aimed at including in French schoolbooks of references to the positive role played by the French colonization in North Africa generated much controversy. In 2021 the historian Benjamin Stora handed to president Macron-who had commissioned it the previous year-a report about "the progress made in France regarding the memory of colonisation and the Algerian War." The negative and hostile reactions that the report generated from both French and Algerian sides showed that various aspects about the narration and memory of colonial history are still sensitive and that there is still no truly inclusive way of telling the past (Stora, „Rapport” 23-26).

During the Algerian War of Independence and after the end of the colonial regime, the National Liberation Front (FLN) became the only ruling party in Algeria and monopolized the war narrative and its heroes. According to Sayad, the FLN built an apparatus of founding national mythologies by selectively combining elements from the recent Algerian past and its pre-colonial history (65). The goals of this practice were-and still are todayboth the creation of an image of the Algerian nation as a strong and cohesive entity and the narration of a monolithic and unitary national history. The slogan "Algeria is my country, Arabic is my language, Islam is my religion” became a catchphrase during the Algerian War of Independence, and was aimed at creating a strong identity in opposition to colonial dominance and its imposition of values. It was repeated and endorsed by the FLN, the ruling party in post-revolutionary Algeria, in order to create a line of continuity with the struggle for independence and to derive a source of legitimacy from it (Calchi Novati and Roggero 59). The slogan strengthened the paradigm of an Arab and Muslim Algeria which, however, marginalized other identities that could not recognize themselves in these definitions. According to Austin, the monopoly of the war narrative created by the FLN for the alleged benefit of the independent nation thus excluded the Berbers, considered a negligible ethnic-linguistic minority if compared to the Arab and Arabic-speaking majority (104). It also excluded the political opponents of the FLN, whose contribution to the revolutionary process was not recognised. It also omitted women and their fundamental 
roles at the level of political, revolutionary, and war experience. This was done because the FLN preferred to develop mythical figures of heroes and martyrs of independence-terms associated exclusively with the masculine - which would be coherent with a "brave, heroic, sometimes macho model of resistance" (Majewska 276).

Before and after 1962, colonialism and nationalism elaborated two narratives of history that made use of different systems of words, symbols, and episodes. Each of the two narratives claimed to be the holder of the truth, and for this reason excluded identities that proposed voices and stories different from the official line. As such, they have been silenced or forgotten. First the colonized people, then FLN's political opponents, Berbers, and women have been excluded or marginalized from the official discourse. For this reason they started looking for a way to inscribe their voices into the official narration of history, although at different times and in different ways.

Specifically, the narrations of women-that were countering the narrative of the colonial and postcolonial state-started to become increasingly articulated during 2000s, due to several determinant factors and events. First, the period of terror and violence known as the "black decade" of the "90s ended. It was during this period that "the role of women emerged as a significant site of ideological, religious, and political struggle" (Flood, "Women Resisting Terror" 109). Moreover, in 1991, Danièle Djamila Amrane-Minne published her historical research, trying to recreate the role played by women in the Algerian War of Independence. Her research was the result of sustained archival work and included interviews with 88 moudjabidate-female militants and fighters for independence (Mortimer 35). Therefore, as Mortimer points out, when the Algerian Civil War ended and the stimulating historiographical work of Amrane-Minne became available, some moudjabidate decided to recount their stories of militancy through memoirs (158).

In 2001, for example, the moudjabida Louisette Ighilahritz published Algérienne, a book in which she recounted her militancy in the FLN, bringing to attention the systematic use of torture by the French army during the Algerian War of Independence (Mortimer 170). In 2012, Zohra Drif Bitat participated in a conference and was confronted by the public, who expected her to disown her past as a militant (Mortimer 160). Bitat wrote Mémoires, in which she shared her path as a militant and her reasons for choosing the armed struggle. She wanted to pass on to the new generations her experience of oppression under the colonial rule, and her perspective on the revolutionary process that lead to independence. In 2013, Eveline Safir Lavalette published Juste Algérienne. She confessed that she had waited all this time, as previously she had not considered it a story worth telling or that could have sparked a wider interest (Mortimer 185).

The stories of the moudjabidate were written forty years after the independence, thus breaking a long and almost continuous period of silence. Up to that moment, the narration of history by female voices had been rare, and historiographic reconstructions with women 
as protagonists had been even less frequent. As I will shortly try to demonstrate, a significant exception to this tendency is Assia Djebar's activity as a director and novelist during the '70s. She placed the narration of history by female voices at the centre of her artistic production (Austin 77).

The silence of the moudjabidate is understandable in light of several considerations. Firstly, memoirs, as well as and historical documentaries, need a time of decompression and meditation before authors are able to process and tell their personal stories and their experience of history. This makes particular sense when we consider that the war-related stories of the moudjabidate are marked by death, violence, imprisonment, and rape. The silence chosen by the moudjabidate was, therefore, a form of self-protection, aimed at securing their personal integrity. This silence also resulted from a feeling of betrayal that the moudjabidate experienced after 1962. Despite the fundamental role played by women during the Algerian War of Independence, their hopes concerning rights and social equality were not answered in the post-war situation. Moudjabidate chose silence and an existence far from the public sphere because the gap between their expectations as revolutionaries and the postcolonial reality was too painful (Mortimer 186). Forty years after the achievement of independence, however, it was necessary to break this silence, as some of the memories were fading away with time, and the moudjabidate were less and less numerous. Their testimonies were, therefore, extremely valuable. In addition to that, the revolutionary experience had empowered women in society-a situation radically different from that of the 2000s, and that could have been used in order to overcome the impasse following the Algerian Civil War.

Since the 2000s, and especially since the 2010s, a number of documentaries have collected the historical reconstruction and memorial work carried out in previous years, and enriched it with a visual dimension. The female-directed documentaries by Algerian and Franco-Algerian directors have tried to recover episodes and figures forgotten by the colonial, postcolonial, and nationalist narrations, and have given them a platform, a face, and a voice. The directors-together with the moudjabidate, the witnesses, and the protagonists of history-have tried to uncover forgotten episodes, and tell the stories of forgotten people, denouncing at the same time heroization narratives, myths and mystifications. As Petty writes, "for women documentary filmmakers in the Maghreb, recovering fragments of submerged histories and memories goes beyond reclaiming the gaze. It is also about listening as a revolutionary gesture, and 'giving voice' to those silenced by official histories and telling their own stories in their own voices" (qtd. in Mortimer 220). However, the perspective of these documentaries is not simply only one of opposition; rather, they fill in the gaps of the official narrations, so that the latter can become truly inclusive of a plurality of experiences and voices. 


\section{Deconstructing myths}

Since the 19th century, the colonization of the Algerian territory was justified, at a theoretical and discursive level, by the idea that Algeria was a tabula rasa, a mostly depopulated territory, ready-or even "made" - to be conquered and occupied. In the colonial interpretation of reality, populations that inhabited this land were people without history and without a culture, that needed to be enlightened and elevated by the French civilizing mission (Jeanson 61). Therefore, the vast territory had to be placed under colonial rule, so that the French regime could make the most of the land and its inhabitants (Jeanson 50).

The writer and director Assia Djebar made her first documentary film, La nouba des femmes du Mont Chenoua, in 1977. The documentary set various records, since it was "the first film by a woman in Algeria, the first film by Assia Djebar, the first time women's histories were inserted into Algerian history, and the first time rural women were given a voice" (Van De Peer 112).

La nouba is set in the mountainous area between Cherchell and Tipaza, in Northern Algeria, not far from the Mediterranean coast. The region is named after Mount Chenoua. It is here that Djebar meets the women who inhabited the land during the colonial period, and records the stories of their everyday lives and of their resistance to colonisation.

There are numerous scenes dedicated to the representation of landscape, which plays an overall important role in the documentary. By showing the landscape and its inhabitantsmostly women-Djebar challenges (and tries to deconstruct) the colonialist perspective of Algeria, depicted as a vast and uninhabited territory. The women of Chenoua live on the land and live thanks to the land and its fruits, as illustrated by the numerous shots of women working in the fields.

In the documentary, female voices reconstruct the story of a continuous, daily resistance to colonisation. In fact, according to Lacheraf, while the French invasion began in 1830which is remembered as the starting year of the French colonial era in Algeria-the Algerian resistance continued in more or less evident forms, but without interruptions, until the First World War (70). According to the definition given by Evans and Philips, the mountains of Kabylia and Aurès were part of the "Algerian dissident territory," by virtue of their historical character of opposition to the dominant power, both in relation to colonial power and the FLN (qtd. in Austin 169). Djebar returned to this mountainous region, which was her native land, to collect stories of resistance in a resilient landscape. The people and the environment were, therefore, united by a shared history of opposition to the ruler, a history that colonialism had tried to erase and deny.

Djebar was aware of the modes of representation characteristic to the colonial era and wanted to confront them. Her intention was to tell the stories of excluded and marginalized people and to regain possession of the means of representation and narration. Djebar's choice 
to use panoramic shots in $L a$ nouba fulfils precisely this purpose. Panoramic shots were an exclusive possibility of the colonial regime. Given that the Algerians did not have aircraft, the aerial images helped feed the French vision of strength, power, and oppression, and were connected to the symbolic perception of the civilizing mission's high ideals (Zarobell 25). With Djebar, panoramic shots were no longer an instrument of control and a symbol of oppression or superiority, but became a further means of demonstrating the communion between human beings and the landscape. Since during colonial times the oppression of the people was accompanied by the desire to possess the land, the consequence was the sexualisation of the landscape. Hence, in Djebar's representation of the landscape, the perspective is doubly renewed, as the eyes looking from behind the camera are the eyes of an ex-colonized woman.

The landscape is not just an environment, a scenario for a story to be told, nor a container. In Djebar's representation, the land is a place of history and is, therefore, relevant, especially as it still bears the traces of the events that took place there. In La nouba, Djebar shows archaeological and funerary sites from pre-colonial times, demonstrating that Algeria was a living and populated land before its colonial occupation, and that the peoples who lived there had their own history and culture- a truth that the colonial narration had long denied. Moreover, several scenes in the documentary show caves where the women of Chenoua perform dances and rituals that strengthen their bond with their tribal past. In addition to the symbolic meaning that the caves have in different cultures, during colonial history the caves were sadly known for the enfumades that took place there-to weaken or exterminate the populations that opposed the colonial occupation and rule, the French army burned the caves causing the death of those who sought refuge in them (Jeanson 41). By filming the caves, Djebar acknowledges the trauma that took place there, but also the strong bond that connects Algerians to their past. However traumatic and painful this past may be, people can still try to write or tell their stories, undiminished and complete (Sharpe 121).

The documentary À Mansourah, tu nous as séparés by director Dorothée-Myriam Kellou has the same aim as Djebar's film: reconstructing the painful story of the separation of Algerians from their land at the hands of the colonial occupation regime. Released in 2019, the documentary tries to collect the oral memories of witnesses and survivors, in order to preserve the individual narratives, and thus to build a collective memory of the events. The story develops around the practices of land expropriation, the round-ups, and the forced displacements that were carried out by the French army throughout the span of colonial history. 2,350,000 Algerians were confined in camps created by the army and surrounded with barbed wire; 1,175,000 were placed in towns and villages guarded by the same army (Kellou "Algérie"). As reported by Kellou, men had to apply for special permits in order to be able to cultivate their lands. In total, more than half of the Algerian rural population was evacuated from their homes and some areas of the country were completely evacuated and 
declared prohibited. In order to justify these practices, the colonial regime stated that the measures were taken so as to protect women and children from the war. Nonetheless, the actions were clearly aimed at weakening tribal and social bonds and at eliminating all forms of support between civilians and resistance militias. According to Kellou, in the long term, the consequences have been dramatic and irreparable. After independence most people did not return to their villages and radically changed their lifestyles: agriculture and crafts were abandoned in favour of wage labour; strong migrations took place from the countryside to the cities and abroad ("Algérie").

Born and raised in France, Kellou went to Mansourah, her father's hometown, to listen to stories of individual and collective violence and deprivation. The narration of the events is thus relevant both as a tool for investigating the past and as a means of preserving memories that would otherwise be lost, but which are fundamental for understanding the historical, social, and economic development of the nation. The questions that Kellou asked are, in fact: "What happens when a society denies its historical suffering and refuses to address its roots? What happens when all you can leave to your descendants are silences and ruins?" ("Algérie"). Telling this story is, therefore, crucial at multiple levels. From a personal point of view, discovering the stories of Mansourah, town where her father spent his childhood before emigrating to France, is a way for Kellou to reconnect with a family past that is part of her personal identity. From a collective and historiographical point of view, the narration of these stories of land and identity deprivation is fundamental, since there are no significant traces of these episodes in the French narration. Even the Algerian narration of colonization has selected some "founding" episodes, but has automatically removed others, however crucial for the understanding of the contemporary reality.

In conclusion, Djebar's and Kellou's documentaries tried to preserve stories and memories and to give voice to more inclusive and participatory narratives, thus attempting to provide a more solid basis for the national construction and reconstruction struggles.

Yasmina Adi's works also tell stories that postcolonial France has chosen to ignore, in order to preserve the myth of the civilizing mission it had in Algeria and the image of a country protecting democracy and freedoms. To this end, Adi's documentaries entered the debate regarding article 4 of the French bill (dated $23^{\text {rd }}$ of February 2005), which proposed introducing a mention in the history textbooks of the positive role played in North Africa by the colonial presence. Adi's documentaries, therefore, wanted to be part of a process of historiographic reconstruction completing the French narration of events. Adi's motivation for this research was certainly reinforced by her being of Algerian descent and living in France. While her primary intention was the exploration of colonial history and the events related to it, her interest could not be separated from a wish to explore her own personal and family origins, the same as in Kellou's case. 
Yasmina Adi's documentaries develop around two crucial dates in Algerian history, dates that are usually omitted from the official French narration, as they bear testimony to the brutality of colonial rule.

Released in 2008, L'autre 8 mai: auxorigines de la guerre d'Algérie reconstructs the events of May 1945 in Algeria. May the $8^{\text {th }} 1945$ is a day of joy in France, marking and celebrating the end of the Second World War and the victory over Nazism. In Algeria, on the other hand, the date represents a day of mourning. On May the $8^{\text {th }} 1945$, demonstrations were organized in various Algerian cities, both to celebrate the end of the war-Algerians, who fought in the French army had a significant contribution to the war effort-but also to ask for greater rights, as well as social and political recognition. At the end of the war the disparities between settlers and colonized people became unsustainable and, from the Algerians' perspective, it was time to start making demands in the political and social spheres. The demonstrationsespecially that organised in the city of Setif, where the future flags of independent Algeria flew for the first time-began in a festive atmosphere, but were subsequently repressed in blood. The protests then moved from the cities to the countryside, and with them the brutal use of force against civilians. The death toll was immediately manipulated, especially by the French army, but the latest and most accurate figures report 40,000 Algerian deaths.

The second date is October the $17^{\text {th }}, 1961$, when the FLN organized a peaceful demonstration in Paris against the imposition of a nightly curfew on Muslims. Thousands of men took part in the demonstration and peacefully paraded from the suburbs-a place where the structural violence of the colonial regime had marginalized them-towards the city centre, a place where they were prevented from staying (Flood, "Politics and the Police" 600). Algerians marched to claim a physical and social space, but their presence in the city centre seemed to be a threat to the established balance of power and representation. Once more, the authorities' response was brutal. It is considered to be the most violent repression of a peaceful demonstration in Europe after the Second World War. Thousands of Algerians were arrested and many others killed during the demonstration itself or during the following few days; their lifeless bodies were abandoned in the streets of the city or thrown into the Seine, where they were later found. Algerians marched to become visible in the city and in society, but the state repression forced them to return to invisibility (Flood, "Politics and the Police” 600). The official narrative has also contributed to this invisibility: more or less officially, the state banned the memory and representation of the massacre and only during the '90s, did "The Battle of Paris" begin to be recognized as such (Einaudi 1991). In 2001, the mayor of Paris officially recognized the massacre by affixing a plaque on the Quai SaintMichel, where some Algerian protesters were drowned. The inscription on the plaque states the following: "In memory of the numerous Algerians killed during the bloody repression of the peaceful demonstration of October $17^{\text {th }}, 1961$ ". The inscription is vague and generates 
uncertainty, since it hides names, numbers, contexts, and reasons, and makes it impossible to fully understand what happened.

Released in 2011, Adi's Here We Drown Algerians: October 17th, 1961 chose to tell this very story. The director listened to the testimonies of witnesses and survivors, so that there is no double repression, first of bodies, then of voices. Adi's work tried, therefore, to shed light on the episodes that characterized colonial history and that were not reflected or echoed in the official narration. The choice to let the protagonists of the events speak and not to entrust the narration to experts responded to Adi's wish to attribute narrative agency to those whose agency had been denied.

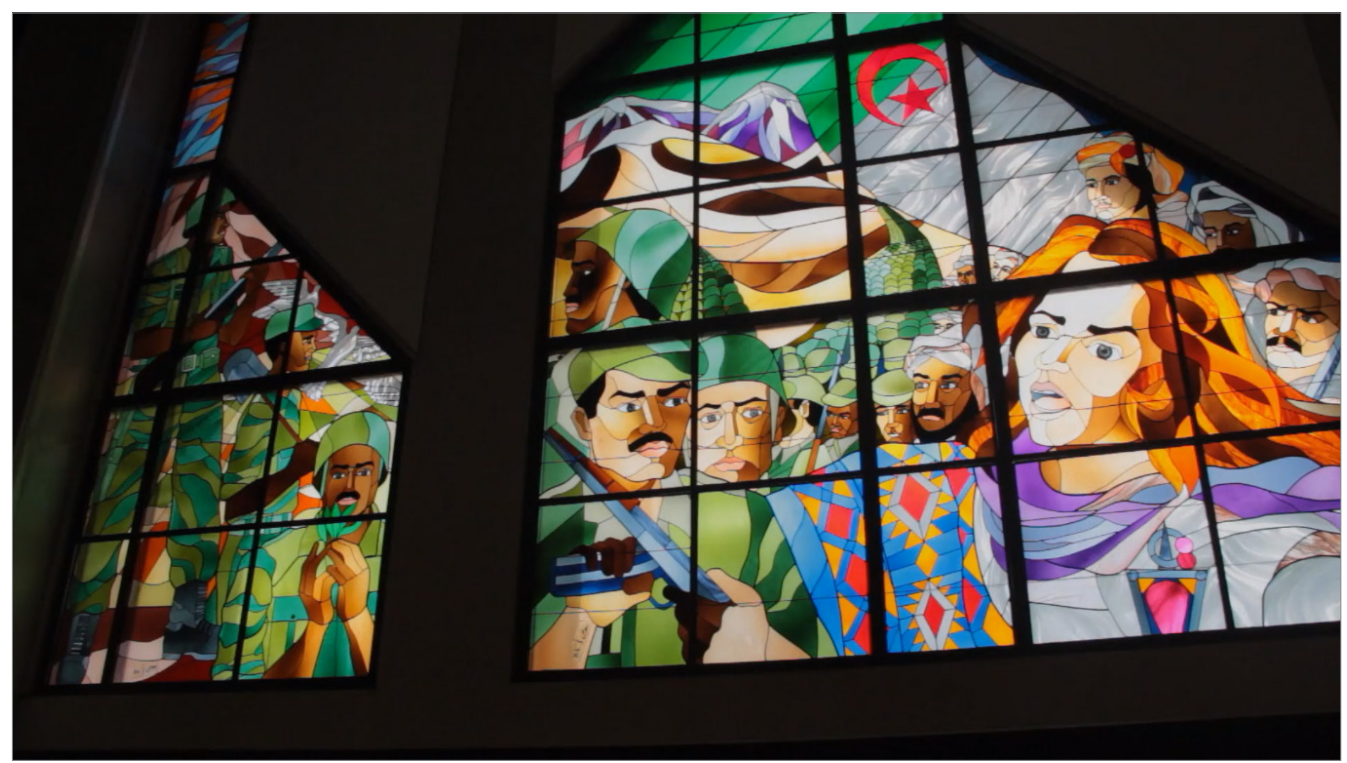

Frame from Guessoum Nassima, 10949 femmes, LE GREC, France, 2014.

Directors Nassima Guessoum and Fatima Sissani focussed their attention on two moudjabidate-female militants in the FLN-who had important, active roles in the revolutionary process, but who were forgotten almost immediately after the achievement of independence.

Released in 2014, Guessoum's 10949 femmes tells the story of Nassima Hablal, one of the 10,949 moudjabidate officially identified by Amrane-Minne in her ample historical and documentation work. In addition to reconstructing Hablal's political profile and her history of resistance and militancy, the director was interested in depicting the personal traits of the moudjabida - her irony, her fragility, and her human vulnerability. Presented through Gouessoum's camera, Hablal's profile is in stark contrast with the mythical imagery of the "heroes of resistance," conveyed by nationalist discourses. The heroic and courageous 
dimension of the moudjabida is not the exclusive focus of the documentary. Instead, her suffering and her disappointment at the lack of recognition after 1962, despite the major role she had played during the revolution, are also represented. In fact, the documentary highlights the fact that there had been no official representatives at Hablal's funeral, while during the fifty-fifth anniversary of independence, President Bouteflika went to pray in memory of the martyrs at the Maqam Echahid, in a riot of flags, during the official celebrations. There were no processions, no crowds, and no official recognition at Hablal's funeral. There was only a coffin wrapped in a flag, before being lowered into the grave, in the presence of only a few acquaintances. This image supports the reading formulated by Khanna, according to which the heroes and the dead of the Algerian revolution are "disposable bodies" that nationalism can arbitrarily use in its discursive and retrospective constructions (19). The mere fact that there is no official register of the war dead-war that is, however, always rhetorically remembered as "the war of the million dead"-confirms the assertion that numbers and names of the dead are not important in themselves (Khanna 27). Instead, it is the mass of the dead "martyrs" from the Algerian War of Independence that the ruling party exploited as a whole to give itself legitimization and a raison d'être.

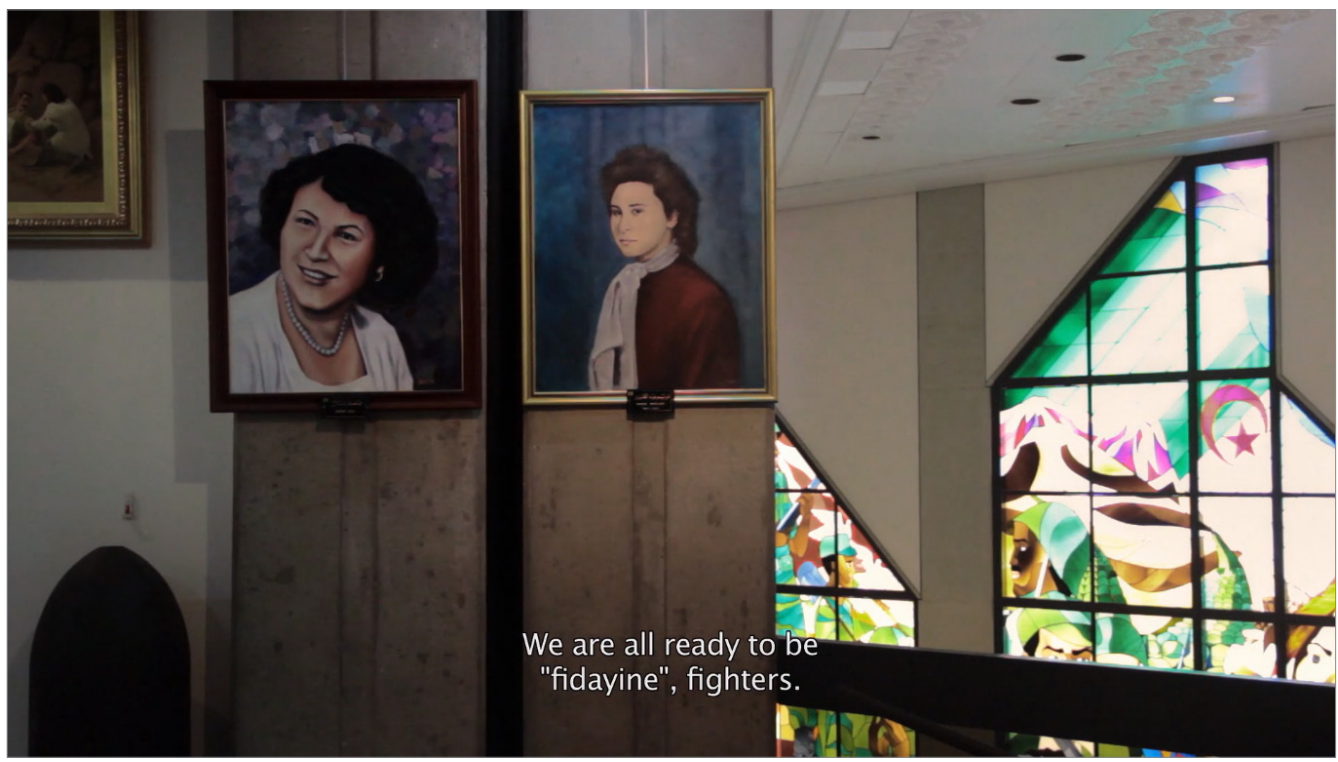

Guessoum Nassima, 10949 femmes, LE GREC, France, 2014 (frame).

The fact that the story focuses on one woman, Nassima Hablal, illustrates the director's wish to give a face to a forgotten protagonist of the war, and thus to remove her from the anonymity that labels such as "moudjabidate" and "FLN" can dissimulate. It also highlights 
her will to give recognition to a woman whose formal political and historical recognition has been denied by the nationalist historiography. On the other hand, Hablal's vulnerability contrasts with the heroic narrative that nationalist discourses have constructed around the fidayate, the women urban fighters responsible, among other activities, with placing bombs and carrying out attacks. The choice to emphasize such a profile has several reasons: first, the masculinization of war and violence implies that only women who were fighting are worthy of memory on a par with men. Those who had a role in political activities and demonstrations, those who supported the movement economically and by hiding militants and weapons were simply left to oblivion (Sharpe 217). Furthermore, the nationalist discourse celebrated and included some women only to corroborate the myth behind the slogan "one hero, the people," which was written on the walls and chanted in during demonstrations. The FLN had always wanted to convey an image of a people united in struggle, beyond gender, political, and ethnic differences. However, this image has never corresponded to reality and, as already mentioned, many identities have been marginalized from 1962 onwards, including women, political opponents of the FLN, and the Berbers (Calchi Novati and Roggero 94).

The documentary Résistantes, tes cheveux démêlés cachent une guerre de sept ans, made by director Fatima Sissani in 2017, records the memories of the moudjabida Eveline Safir Lavalette. Although born and raised in a rich family of settlers, Lavalette was moved by the discrimination and violence perpetuated against the colonized people and decided to embrace the cause of Algerian independence. As in the case of Guessoum's 10949 femmes, the relationship between the director and the subject developed over a long period of time and was marked by a high degree of intimacy. Both directors spent long hours with their subjects; however not all of their time together was filmed and included in the documentary. This time spent together aimed to create relationships that avoided asymmetrical and impersonal modes of representation.

There is a striking difference between the perspective adopted by the two aforementioned documentaries and the colonizers' representation of the colonized. Through visual methods, such as photography and documentaries, colonial representation has always been characterized by a strongly unbalanced power relationship-who represented who has always been clear (Said 72-74). In Sissani's documentary, the dimension of fragility and vulnerability that characterizes Guessoum's portrait of Hablal is lost, and Sissani's representation of Lavalette remains limited to her role as moudja hida. Sissani presentation, just as Guessoum's, welcomes a variety of voices: the stories of Hablal and Lavalette are, in fact, told by themselves, but are complemented by the testimonies of other moudjabidate. Once again, a line of continuity, common to all the documentaries, can be observed-plurality is the only guarantee of truth. The directors were aware of the fact that the colonialist and nationalist discourses deployed monolithic and unitary narratives, thus excluding certain particular identities. For this reason, they chose to entrust the telling of the story to a plurality of narrators. Only this way 
could the narration of history be the bearer and interpreter of diverse experiences, restoring the prism of nuances that compose reality, far from all simplifications and mythologizations.

The last documentary to be analysed in this round-up, Les porteuses de feu by Faouzia Fekiri, was made in 2007 and directly confronts the mythical image of the fidayate, the FLN women fighters. Although they represented only a small minority, the depiction of the fidayate has been more frequent and popular than that of the other moudjabidate, for the previously listed reasons, and as illustrated by the following three famous examples (Mortimer 27-28).

The first is the 1958 film Jamila the Algerian, made by Egyptian director Youssef Chahine. The film offered a very positive and heroic portrayal of the most famous of the fidayate, Djamila Bouhired. Chahine made the movie in order to support the request for Bouhired's release during the Algerian War of Independence. The second, in 1966, is a scene from the film The Battle of Algiers by Italian director Gillo Pontecorvo. Inspired by a real episode from the Algerian War of Independence, the scene shows the placing of bombs by three poseuses de bombes, in three different locations of the French-occupied part of Algiers. The women protagonists are, however, depicted without names, voices, or motives. The third is the 1969 short film La bombe, made by Rabah Laradji. While it has strong technical and artistic affinities with the scene in Pontecorvo's movie, the film recounts a fictional, yet likely, episode, in which Nadia, a young Algerian, decides to carry out a bombing to avenge her brother's death, and dies as a result in the attack.

In the realization of her documentary, Fekiri was aware of these representations of fidayate and therefore decided to challenge them. In her Les porteuses de feu she met Fatima Loudarene, known as Louiza, Fettouma Ouzeguène and Zohra Drif Bitat, fidayate who were active militants in the FLN during the battle of Algiers. Fekiri reconstructed their history of militancy, their actions, and the motivations behind their choice to embrace the armed struggle. Uninterested in delineating a heroic or mythologized profile, Fekiri gave them narrative agency, names, and faces, so as to give them the opportunity to reconstruct their roles in the war, to express their motivations, and to evaluate the historical events they participated in from a personal point of view.

\section{Documentaries as counter-narration}

In line with Asen's definition of counterpublics as "explicitly articulated alternatives to wider publics that exclude the interests of potential participants," (424) the documentaries previously mentioned propose alternative narratives to the established and official discourses. First of all, these documentaries were made following the "recognition of exclusion" and marginalization that Asen described (427). According to the directors, facts 
and people excluded from the colonial and nationalist discourses must be remembered and represented.

Also, as Fraser argued, exclusion, and therefore opposition, is always twofold and this reading is confirmed in the aforementioned documentaries: not only do female directors choose to tell stories that relate-in contrast or integration - with colonialist and nationalist narratives, but they also intend to break the divide between public and private spheres (qtd. in Majewska 272). In fact, ordinary people who tell their stories in documentaries bring their own, personal, daily experiences of resistance into the public sphere, showing the permeability between the two domains, as already theorized by Habermas (15). The action of opposition and integration expressed in the documentaries is aimed at highlighting a different model of resistance: at the level of the represented subjects, the resistance is not identified in a "heroic, macho model of resistance," but in the daily struggle of men and women against violence, the colonial and nationalist discourse, also showing the vulnerabilities and fragilities of these protagonists (Majewska 276). In relation to documentary-making work, the opposition is to a monolithic, exclusive narration, as these documentaries return agency to language, both for the directors and for the subjects. This choice demonstrates a "belief in the transformative power of discourse," since it manages to establish alternative narrative norms (Asen 429). Documentaries are thus constituted as "potentially emancipatory affirmative practices with the hope that power may be reconfigured" (Asen 425). It is important to note, as we have already tried to highlight, that the discourse developed in the documentaries opposed what colonialism and nationalism stood for. Female directors, aware of the official narration models, have tried to create their documentaries in antithesis with the dominant narratives. Nevertheless, there is not only contradiction between their stories and the official accounts, since the directors' wish seems to also have been that of introducing and integrating these marginal narratives into the dominant public sphere.

The main narrative device adopted by these documentary makers is the safeguarding of plurality: there is never a single narrator and a unique point of view; rather, the narration is made possible by the polyphony of narrators, witnesses, and participants. On the whole, the documentaries analysed in this essay constitute "mutually interlocking and overlapping networks" (Asen 424). As such, they succeed in depicting the social and historical complexity of events. The female directors' works previously discussed are not limited to a single subject, a single place, or a single topic. Instead, they focus on different points of view that can complement each other and contrast with the dominant narrative. From this perspective, it is difficult to identify a movement of postcolonial documentaries directed by women, since the documentaries deal with different topics and issues, and each of them is also unique from a technical and stylistic point of view. In fact, as Felski points out, a counterpublic sphere may consist in a collective action that never converges to form a single, coordinated movement (qtd. in Asen 428). 
Since all the documentaries focus on the narration of specific stories, there is no affirmation of universality. It is, however, the shared experience of oppression, be it colonial or postcolonial, that generates communality and inspires the creation of an oppositional narrative. The shared experience of oppression and the recognition of exclusion creates a certain resistance to forgetfulness, as clearly exemplified by the effort put into collecting stories and experiences at risk of oblivion. In fact, as demonstrated by the experience of the moudjabidate, who were active in the war, but forgotten immediately after it, "counterpublics gains are not permanent" (Asen 442). Indeed, the official public discourse can try to incorporate counter-narrations-for instance the mythical representation of the fidayate-only to obtain greater political leverage and legitimacy, as it happened with the nationalist recuperations of the "heroic" female fighters.

These documentaries therefore focus on excluded or marginalised people, highlighting their experiences and struggles as a form of counterdiscourse. As the works of Djebar, Kellou, and Adi show, the contradiction is mainly with the colonial distinction between colonizing peoples (actors of history and authors of archives), and colonized peoples (without history and culture). The opposition is also to nationalism, which promoted an apparently inclusive narrative, while, in reality, it was strongly limited and discriminatory, as Guessoum's and Sissani's documentaries reveal.

Some directors also decided to let women tell their stories in order to contrast them with the patriarchal outlook, dominant in the social and discursive spheres. Women experienced empowerment during the Algerian War of Independence and this is why Djebar, as well as the historian Amrane-Minne, dedicated their work to this period. In the 2000s, directors followed the same path, revealing that, regrettably, women's testimonies-past and present-continued to be neglected, in order to advantage the narration of history by men and for men. Nevertheless, in spite of this implicit bias structuring the public sphere, counter-narrations could be articulated and presented by female directors. Their activity is particularly interesting as a practice of writing back or rewriting colonial, national, and patriarchal histories from a more inclusive perspective. First and foremost, their work is a process of collecting and recording oral history. Just like Amrane-Minne's historic work, the directors carried out extensive research before starting to shoot their documentaries. By carefully selecting their sources, they have tried to recover and transmit an oral, fragile memory, thus treasuring the narrators' dramatic and revolutionary experiences.

Precisely because they had to face different types of limitations and biases-colonial, postcolonial, nationalistic, or patriarchal-some of these documentaries have also witnessed different forms of censorship and opposition. For example, after producing it, the Radio Télévision Algérienne aired La nouba by Djebar only once. Moreover, the documentary was not included in the publication celebrating national cinema on the occasion of the thirtieth anniversary of the Algerian revolution. Nassima Guessoum's documentary 10949 femmes 
was screened only twice in Algeria before being banned. After hundreds of screenings and participation in various festivals, the screening in 2019 of Fatima Sissani's Résistantes at the Utopie cinema in Sainte-Livrade was cancelled, following threats to burn the cinema down and because of the violent demonstrations that opposed its screenings. Various cultural organizations condemned the protests and the cancellation of the film, and decided to organize several simultaneous screenings of the film in various locations in France, defending the freedom of expression of "female fighters yesterday and today."

In addition to a somewhat official erasure and mystification of history, there is also resistance to the making and distribution of documentaries and to their "efforts to reconfigure the discursive practice" (Asen 426). However, as Majewska points out, "restrictions of artistic freedom, including censorship or other political limitations, are productive, they generate results" (275), since directors are able to focus attention on otherwise muted and marginalized elements. Finally, censorship sometimes generates greater resonance, as in the case of the simultaneous screenings of Sissani's documentary.

Control, be it colonial, patriarchal, or national, constitutes a force that structures subjects and society, contributing to the birth and development of "parallel discursive arenas, where members of subordinated social groups invent and circulate counter discourses to formulate oppositional interpretations of their identities, interests, and needs" (Fraser 67). The subjects, as illustrated in the aforementioned documentaries, express their own distinctiveness against the homogenization that the dominant discourses attempt to impose. The directors therefore try to oppose the mythological production machine which, in Jesi's definition, is the device that generates "mythologems" - that is historically-verifiable stories that produce concrete effects on reality, but that refer to a secret origin, i.e. a myth that remains unknowable by definition (10). Both colonialism and nationalism are mythological machines that make use of linguistic systems generating "clichés, stereotypes, [and] fixed formulas" (Jesi 11). In other words, a system of myths and symbols reinforces the two discourses and makes their messages more easily understandable and transmissible, but fixed. These types of discourses are based on a past that Jesi defines as "reduced to a shapeless jelly," providing arbitrary elements that can be manipulated in order to obtain a discourse consistent with particular political and social aims (16). Documentaries contrast these mythological machines but do not try to destroy them, since "they would reform like the heads of the hydra"; instead, they try to modify the situation that makes the mythological machines work (Jesi 19). Opposition to the mythological machine and modification of the situation are political acts that firmly place documentaries in one or more historical, geographical, and cultural context(s).

Finally, the documentaries respond to exclusion and expand the public debate, which is a characteristic of counterpublics, as noted by Fraser (69). Documentaries thus constitute spaces for collecting stories, characters, and memories, but they are also spaces for agitation. They are, in fact, "aesthetically and theoretically exciting, historically embedded, politically 
engaged, and future-oriented" works (Moore 157). Being placed in a particular historical and geographical context, with an eye to the future and another to the preservation of past stories, these documentaries take part in the political, historical, and social debates. For this reason, as in the case of Adi's documentaries and the discussion regarding the French colonial presence in North Africa, they also play a political role. Another relevant example is Fekiri's documentary Les porteuses de feu, which started a debate about the ways in which fidayate are represented. A criminal case was opened against the director, who was accused of apologizing for terrorism, since the victims of attacks made by the fidayate felt offended and disrespected. Similarly, a screening of Sissani's documentary was cancelled because it was considered to be damaging to particular sensitivities and identities. Furthermore, especially in recent times, documentaries have found their way into the heart of protest movements, as it happened with Guessoum's and Sissani's works. In fact, their documentaries were screened at conferences-sometimes in the presence of the directors-during the hirak (the Algerian movement of protest against a fifth term of president Bouteflika and in favour of profound structural reforms, which started in February 2019). These links between directors, events, documentaries, and subjects demonstrate that a counterpublic is not a closed group that generates an inside/outside dynamic, as Asen highlights (432). On the contrary, counterpublics allow a transversal approach and a plurality of identifications. The identity that shapes the counterpublic, already identified in the experience of oppression, is relevant, but it is not a unique and exclusive dimension, at risk of generating in its turn a monolithic and marginalizing narrative (Asen 432). Finally, the analysed documentaries have the character of "simultaneity, permeability, different affiliation and partiality" typical for counterdiscourses, as demonstrated by the fact that they are still relevant for today's debates around sensitive points - in France and in Algeria — and that their message is transversal and receivable by different groups at different times (Asen 441).

\section{Conclusions}

The documentaries discussed in this essay are significant examples of counter-narration, both in contemporary French and Algerian societies. Identifying the public sphere as the custodian of public opinion, they try to filter new messages and languages inside it. Through their discursive strategies, documentaries identify the state-be it postcolonial or nationalist—as the public of their discourse, or the "desired audience," as Asen calls it (443).

The attention given to historical events and the recovery of silenced voices highlight the different regimes of marginalization that need to be opposed. As shown by the connection between subjects, documentaries, and contemporary historical events, a counter-discourse is not a closed entity. Its ability to insert arguments into wider publics-thus generating 
"transformations in the collective understanding of the common good," and the rediscovery of what was previously marginalized - redefines, on a non-exclusionary basis, the notion of common interest (Asen 435).

\section{Works Cited}

ASEN, Robert. "Seeking the 'Counter' in Counterpublics." Communication Theory, 10(4), 2006, pp. 424-46.

AUSTIN, Guy. Algerian National Cinema. Manchester University Press, 2016.

CALCHI NOVATI, Giampaolo and Caterina Roggero. Storia dell'Algeria indipendente: dalla guerra di liberazione al fondamentalismo islamico. Milano: Bompiani, 2018.

EINAUDI, Jean-Luc. La bataille de Paris. 17 octobre 1961. Paris: Seuil, 1991.

FLOOD, Maria. "Politics and the Police: Documenting the 17th October 1961 Massacre." Contemporary French and Francophone Studies, 20:4-5, 2016, pp. 599-606.

---. "Women Resisting Terror: Imaginaries of Violence in Algeria (1966-2002)." The Journal of North African Studies, Vol. 22, No. 1, 2017, pp. 109-31.

FRASER, Nancy. "Rethinking the Public Sphere: A Contribution to the Critique of Actually Existing Democracy.” Social Text, No. 25/26, 1990, pp. 56-80.

HABERMAS, Jürgen. Storia e critica dell'opinione pubblica. Bari: Laterza, 1971.

JEANSON, Colette and Francis Jeanson. Algeria fuorilegge. Milano: Giangiacomo Feltrinelli Editore, 1956

JESI, Furio. Cultura di destra. Con tre inediti e un'intervista. Roma: nottetempo, 2011.

KHANNA, Ranjana. Algeria Cuts. Women EंRepresentation, 1830 to the present. Stanford University Press, 2007.

KELLOU, Dorothée Myriam. "Algérie : « Mansourah et le fantôme de mon père »." Le Monde, 23.01.2021, <https://bit.ly/3omDIaT>. Accessed May 21, 2021.

LACHERAF, Mostefa. L'Algérie: Nation et société. Paris: Maspero, 1965.

MAJEWSKA, Ewa. "Art as Counterpublics? Modes of Resistance in Contemporary Culture." Przeglad Kulturoznawczy, 3(41), 2019, pp. 271-86.

MOORE, Lindsey. Arab, Muslim, Woman. Voice and vision in postcolonial literature and film. Routledge, 2008.

MORTIMER, Mildred. Women Fight, Women Write. Texts on the Algerian War. University of Virginia Press, 2018.

SAID, Edward W. Orientalismo. L'immagine europea dell'Oriente. Milano: Giangiacomo Feltrinelli Editore, 2019.

SAYAD, Abdelmalek. Algeria: nazionalismo senza nazione. Messina: Mesogea, 2003.

SHARPE, Mani. "Representations of space in Assia Djebar's 'La nouba des femmes du Mont Chenoua'." Studies in French Cinema, Vol. 13, N. 3, 2013, pp. 215-25. 
STONE, Martin. The Agony of Algeria. London: Hurst and Co., 1997.

STORA, Benjamin. La guerra d'Algeria. Bologna: il Mulino, 2009.

---. "Rapport. Les questions mémorielles portant sur la colonisation et la guerre d'Algérie,” January 2021, <https://cutt.ly/abkISQL>. Accessed May 21, 2021.

VAN DE PEER, Stefanie. Negotiating Dissidence: The Pioneering Women of Arab Documentary. Edinburgh University Press, 2017.

ZAROBELL, John. Empire of Landscape: Space and Ideology in French Colonial Algeria. Pennsylvania State University Press, 2010.

\section{Filmography}

À Mansourah, tu nous as séparés. Directed by Dorothée-Myriam Kellou, Les Films du Bibloquet, HKE Production, Lyon Capitale TV and Sonntag Pictures, 2019.

Ici on noie les Algériens. Directed by Yasmina Adi, Institut national de l'audiovisuel, 2011.

La battaglia di Algeri. Directed by Gillo Pontecorvo, Casbah Film and Igor Film, 1966.

La bombe. Directed by Rabah Laradji, ONCIC, 1969.

La nouba des femmes du Mont Chenoua. Directed by Assia Djebar, RTA, 1976.

L'autre 8 mai 1945. Aux origines de la guerre d'Algérie. Directed by Yasmina Adi, Compagnie des

Phares et Balises, CPB Films, and France 2, 2008.

Les porteuses de feu. Directed by Faouzia Fekiri, France 3, and BFC Productions, 2007.

Résistantes, tes cheveux démêlés cachent une guerre de sept ans. Directed by Fatima Sissani, 24 Images,

Thelma Film, and Djinn productions, 2017.

10949 femmes. Directed by Nassima Guessoum, LE GREC, 2014. 